УДК 330.341.1:339.137.2

\title{
ІННОВАЦІЙНИЙ РОЗВИТОК У МЕХАНІЗМІ ЗАБЕЗПЕЧЕННЯ ГЛОБАЛЬНОЇ КОНКУРЕНТОСПРОМОЖНОСТІ ПІДПРИЕМСТВ
}

\author{
Уткіна Ю.М., к.е.н., доцент, \\ Остапюк Б.Я., к.е.н., ст. викладач (УкрДУЗТ)
}

Світові економічні тренди демонструють об'єктивну необхідність забезпечення інноваційності розвитку підприємства як передумови його виживання у глобальному конкурентному середовищі. $B$ умовах глобальної конкуренції саме інновачійний чинник визначае парадигму успішного економічного розвитку $i$ забезпечення економічної безпеки держави. Посилення конкурентної боротьби на глобалізованих ринках потребує від усіх краӥн, які намагаються стати успішними гравиями на світовому економічному просторі, виваженої стратегії економічного розвитку та застосування ефективних динамічних механізмів утвердження, закріплення своїх стійких позицій на міжнародному ринку. Необхідною умовою для цього є формування в країні потужного конкурентоспроможного середовища, яке базується на інновачійних чинниках $i$ забезпечуе прорив на міжнародні ринки високотехнологічної продукиії.

Ключові слова: глобальна економіка, конкурентоспроможність, інноваційний розвиток, міжнародна конкурентоспроможність, підприємство.

\section{ИННОВАЦИОННОЕ РАЗВИТИЕ В МЕХАНИЗМЕ ОБЕСПЕЧЕНИЯ ГЛОБАЛЬНОЙ КОНКУРЕНТОСПОСОБНОСТИ ПРЕДПРИЯТИЙ}

\author{
Уткина Ю.М., к.э.н., доцент, \\ Остапюк Б.Я., к.э.н., ст.преподаватель (УкрГУЖТ)
}

\begin{abstract}
Мировые экономические тренды демонстрируют объективную необходимость обеспечения инновачионности развития предприятия как предпосылки его выжсивания в глобальной конкурентной среде. В условиях глобальной конкуренции именно инновачионный фактор определяет парадигму успешного экономического развития и обеспечения экономической безопасности государства. Усиление конкурентной борьбе на глобализированных рынках требует от всех стран, которые пытаются стать успешныли игроками на мировом экономическом пространстве, взвешенной стратегии экономического развития и применение эффективных динамических механизмов утверждения, закрепления своих устойчивых позищий на международном рынке. Необходимым условием для этого является формирование в стране мощного конкурентоспособного среды, которое базируется на инновационных факторах и обеспечивает прорыв на международные рынки высокотехнологичной продукции.
\end{abstract}

Ключевые слова: глобальная экономика, конкурентоспособность, инновационное развитие, международная конкурентоспособность, предприятие.

(C) Уткіна Ю.М., Остапюк Б.Я.

Вісник економіки транспорту і промисловості № 61, 2018 


\title{
THE INNOVATIVE DEVELOPMENT MECHANISM OF GLOBAL COMPETITIVENESS OF ENTERPRISES
}

\author{
Utkina Yu.M., Ph.D. in Economics, associate Professor \\ Ostapyuk B.Y., Ph.D. in Economics, Senior Lecturer (UkrSURT)
}

Global economic trends demonstrate the objective necessity of ensuring the innovative development of enterprises as a prerequisite for its survival in a global competitive environment. For the domestic enterprises innovative development is essentially the only prerequisite for their survival and potential to reach global markets. In this context, we are talking not only about technological or product innovations, which, because of lack of resource provision activities are a serious problem for implementation, but also managerial, marketing and organizational innovations. It is this kind of innovation can be not only an effective prerequisite for their sustainable development, but also a catalyst for the building of all components of innovative capacity that will provide a comprehensive innovative development of the enterprise. In terms of global competition, it is the innovation factor defines a paradigm of successful economic development and the economic security of the state. The increased competition in globalised markets demands that all countries who are trying to become successful players on the global economic environment, balanced economic development strategy and the application of efficient dynamic approval mechanisms, consolidate their sustainable position in the international market. The prerequisite for this is the formation of a strong competitive environment, which is based on innovation factors and provides a breakthrough to the international markets of high-tech products.

Keywords: global economy, competitiveness, innovation development, international competitiveness, enterprise.

Постановка проблеми та її зв'язки 3 науковими чи практичними завданнями. Процеси трансформації, що відбуваються сьогодні у світовій економіці, дають підстави констатувати процес формування глобального ринку, для якого характерні такі тенденції: динамічне зростання місткості ринку, ускладнення його структури, збільшення кількості учасників та посилення вимог до ïx конкурентоспроможності; залучення господарюючих суб'єктів до формування глобального попиту та глобальної пропозиції; зростання чутливості національних економік до змін глобального середовища; проектування, розширення масштабів виробництва глобалізованих продуктів і послуг; набуття процесами злиття та поглинання наднаціонального характеру; формування глобальної системи управління у процесі інституціалізації, лібералізації та дерегулювання фінансових ринків; перехід до економіки знань; збільшення частки об'єктів інтелектуальної власності на світовому ринку; уніфікація та стандартизація ринку праці на глобальному рівні, посилення взаємозалежності національних ринків праці в процесі формування глобального ринку праці.

Світові економічні тренди демонструють об'єктивну необхідність забезпечення інноваційності розвитку підприємства як передумови його виживання у глобальному конкурентному середовищі. Для вітчизняних підприємств забезпечення інноваційного розвитку $\epsilon$, по суті, єдиною передумовою їх виживання та потенційного виходу на світові ринки. У цьому контексті мова йде не лише про технологічні чи продуктові інновації, які в силу нестачі ресурсного забезпечення діяльності становлять неабиякі проблеми

Вісник економіки транспорту і промисловості № 61, 2018 
щодо реалізації, але й про управлінські, маркетингові та організаційні інновації. Саме такий вид інновацій може стати не лише дієвою передумовою для їх стійкого розвитку, але й каталізатором до нарощення усіх складових інноваційного потенціалу, що в майбутньому забезпечить комплексний інноваційний розвиток підприємства.

Аналіз останніх досліджень i публікацій. Питання щодо визначення сутності, факторів впливу та напрямків інноваційного розвитку підприємств в аспекті конкурентоспроможності розкрито у працях багатьох науковців. Зокрема, на нашу думку, слід виділити дослідження В.Л. Диканя [3-5], В.М. Гриньової, О.В. Козиревої [2], С.М. Ілляшенко [7], Л.І. Федулової [8] та ін. У працях науковців розкриваються різноманітні аспекти інноваційного розвитку українських підприємств в умовах інтеграції економіки України у глобальну світову систему.

Виділення невирішених частин загальної проблеми. Більшість передових промислових підприємств i організацій України усвідомили необхідність проведення інноваційної політики, проте невизначеність в структурній перебудові економіки і інші чинники, обумовлені національним менталітетом, перешкоджають приєднанню українських бізнесменів до світових інноваційних процесів. Перед українськими менеджерами в умовах нестабільності законодавчої діяльності державних органів в перехідний період виникають складні проблеми, від рішення яких часто залежить само існування підприємства. За даними соціологічних досліджень, на ці проблеми окрім об'єктивних чинників впливають низька якість менеджменту, нездатність багатьох менеджерів максимально використовувати творчий потенціал персоналу підприємства. Отже, на нашу думку, недостатньо опрацьованим залишаються питання щодо місця інноваційного розвитку у механізмі забезпечення глобальної конкурентоспроможності підприємства.

\section{Формування цілей статті} (постановка завдання). Саме тому метою даного дослідження $\epsilon$ обгрунтування теоретичних засад інноваційного розвитку підприємств України в умовах наростання глобалізаційних тенденцій на світових конкурентних ринках.

Виклад основного матеріалу дослідження. Для України проблема збереження конкурентних позицій на світовому ринку стоїть особливо гостро, бо в сучасних умовах втрачаються ті фактори, які могли б забезпечити зростання конкурентоспроможності у майбутньому. На зовнішньому ринку продукція більшості українських виробників може бути реалізована тільки в рамках демпінгових і нелегальних угод. На світовому ринку конкурентоспроможними визнано менше $1 \%$ українських товарів і послуг. Неможливо також говорити про прибутковість українського виробництва та експортних операцій. Зробивши аналіз, можна дійти висновку, що основними проблемами конкурентоспроможності українських підприємств, як на зовнішньому, так i на внутрішньому ринках, є: нездатність виробляти товари, що забезпечують для громадян високий рівень життя, а також зберегти цей рівень на довгий термін; нездатність у рамках вільних ринкових умов виробляти товари та послуги, що відповідають вимогам міжнародного ринку; нездатність країни домогтися високих темпів збільшення приросту ВВП на душу населення; нездатність підтримувати відносно високий рівень показників доходу та зайнятості населення.

Використовуючи досвід зарубіжних країн, структурна перебудова української економіки повинна бути орієнтована на використання інтелектуальних ресурсів i розвиток високотехнологічних виробництв. Усе це передбачає створення

Вісник економіки транспорту і промисловості № 61, 2018 
умов для безперервного оновлення технологій i асортименту продукції, зростання освітнього рівня та вдосконалення управління шляхом упровадження інновацій та науковотехнічних досягнень, заснованих на новітніх знаннях i технологіях. Серед пріоритетних напрямків діяльності з точки зору підвищення конкурентоспроможності українських підприємств можна виділити: імпортозаміщення виробництва; інформаційні технології; телекомунікації і зв'язок; безвідходне виробництво; охорону навколишнього середовища.

Трансформація економіки України викликає необхідність у нових підходах до проблеми якості та конкурентоспроможності; вимагає більш повного врахування виробниками ринкового фактору, зсуву від адміністративних важелів контролю якості до переважно організаційно-економічних заходів управління якостями; організації роботи 3 переходу у перспективі до тотального забезпечення якості. У силу своєї комплексності i багатогранності якість - проблема, що вимагає на рівні промислового підприємства форми узгоджених зусиль усіх підрозділів для прийняття рішень. Узгодженість зусиль неодмінна умова підтримки якості продукції на необхідному рівні. Щоб дана умова дотримувалася в повній мірі, необхідна чітка програма дій, в якій формулюються цілі та завдання.

Отже, в умовах глибоких національного ринку головне завдання підприємства полягає у знаходженні своєї ніші в жорстких умовах конкуренції на світовому ринку. Для цього підприємство, що діє в глобальній економіці, повинно враховувати особливості сучасного ринку. На перше місце в умовах глобальної економіки виходять такі чинники підвищення конкурентоспроможності підприємства: проведення інноваційної політики, яка визначає можливість підприємства конкурувати не тільки на внутрішньому, а й на зовнішніх ринках; наявність кваліфікованих трудових ресурсів, що відповідають вимогам міжнародного ринку праці; гнучка система управління якістю на підприємстві. Підприємство, чия стратегія визначається як глобальна, повинно враховувати також культурні, соціальні, політичні, технологічні, екологічні та юридичні особливості ринку окремо взятої країни.

$\mathrm{y}$ більшості випадків як $\mathrm{y}$ дослідженнях вітчизняних, так і іноземних науковців термін «інноваційний розвиток» використовується, коли йдеться про відповідний тип розвитку на макрорівні i проводяться дослідження щодо механізму реалізації науково-технічного прогресу в процесі економічного розвитку країни, регіону, формування так званої економіки знань, пошуку нових джерел економічного зростання, побудови державної інноваційної моделі розвитку тощо. При цьому під інноваційним типом розвитку розуміють спосіб економічного зростання, заснований на постійних і систематичних нововведеннях, спрямованих на суттєве поліпшення всіх аспектів діяльності господарської системи, на періодичному перегрупуванні сил, обумовленому логікою НТП, цілями i завданнями розвитку системи, можливістю використання певних ресурсних факторів у створенні інноваційних товарів i формуванні конкурентних переваг, а інноваційною вважають таку модель розвитку, яка безпосередньо грунтується на отриманні нових наукових результатів та їх технологічному впровадженні у виробництво, забезпечуючи приріст ВВП головним чином за рахунок виробництва $\mathrm{i}$ реалізації наукоємної продукції та послуг.

Складні цивілізаційні процеси постійно окреслюють перед підприємствами нові завдання, а тому для успішного функціонування останніх важливо своєчасно вносити необхідні зміни у напрямки їх розвитку з метою відображення в їх розвитку досягнень науково-технічного прогресу та вимог

Вісник економіки транспорту і промисловості № 61, 2018 
середовища їх функціонування. За умов швидких змін на світових ринках пріоритетної ролі набувають завдання радикальної переорієнтації діяльності підприємств на нові потреби споживачів із врахуванням сучасних суспільних вимог. Однак на сьогодні сучасні вітчизняні підприємства мало уваги акцентують на пошуку інноваційних напрямів діяльності, що в кінцевому випадку призводить до втрати ринків збуту, не вчасній реакції на суспільні виклики в економіці, соціальній та екологічній сфері.

Визначення

напрямку

інноваційного розвитку залежить не лише від спонукальних мотивів підприємства, але й через зіставлення вигод, отриманих споживачем при використанні інноваційної продукції, ii ціни, порівнянням ефекту від впровадження нововведень і вкладеного інноваційного капіталу. За умови перевищення інтегральної оцінки вигод при використанні інноваційної продукції над оцінкою ціни, і перевищення ефекту від впровадження нововведень над вкладеним інноваційним капіталом, напрямок інноваційного розвитку називається «всебічні переваги». На практиці найбільш застосовуваними напрямами інноваційного розвитку є:

- впровадження енергозберігаючих технологій та нетрадиційних видів енергоресурсів;

- впровадження безвідходних та маловідходних технологій;

- впровадження комплексних

інформаційних технологій;

- використання принципово нових матеріалів та ресурсів;

- розробка i впровадження наукоємних технологій;

- підготовка висококваліфікованих кадрів;

- проведення якісних змін капіталу та фінансової структури підприємства;

- впровадження нової організації праці та виробництва - створення систем науково-технологічного, інформаційного, кадрового, маркетингового забезпечення інноваційного розвитку;

\section{- впровадження прогресивних}

систем управління.

При створенні інновацій слід враховувати, що зміни у середовищі функціонування підприємства відбуваються часто, тому існує нагальна потреба в комплексному аналізі, моніторингу і прогнозуванні потенційних викликів.

Глобальна конкуренція $\mathrm{\epsilon}$ динамічним організмом, що постійно змінюється, ускладнюється за формою та змістом, потребуючи фундаментальної переоцінки основ забезпечення конкурентоспроможності, нової системності та методичності їі побудови. За умов глобальної конкуренції конкурентні переваги, яких підприємство досягло, діючи на своєму національному ринку, доповнюються тими перевагами, які з'являються при проведенні міжнародних операцій (наявність заводів у країнах 3 дешевою робочою силою, здатність задовольняти попит споживачів за рахунок власних міжнародних операцій, репутація фірми, що поширюється за межі однієї країни). Сила позицій підприємства в умовах глобальної конкуренції прямо пропорційна тому набору конкурентних переваг, які воно має у своїй країні.

Аналізуючи еволюцію визначення концепції конкурентоспроможності, можна констатувати, що у процесі розвитку конкуренція якісно видозмінюється своєю структурою, динамікою, масштабами. Одночасно породжувались якісно нові проблеми економічного розвитку країн у глобальному середовищі, пов'язані 3 міждержавними, міжцивілізаційними взаємодіями, формувалися умови для світової (глобальної) інтеграції, за якої спеціалізовані економічні суб'єкти могли функціонувати i змагатися у володінні ринками. Тому у революціонізуючій світогосподарській системі виникла

Вісник економіки транспорту і промисловості № 61, 2018 
потреба акцентувати увагу на дослідженні глобальної конкуренції.

В умовах глобальної конкуренції саме інноваційний чинник визначає парадигму успішного економічного розвитку i забезпечення економічної безпеки держави. Посилення конкурентної боротьби на глобалізованих ринках потребує від усіх країн, які намагаються стати успішними гравцями на світовому економічному просторі, виваженої стратегії економічного розвитку та застосування ефективних динамічних механізмів утвердження, закріплення своїх стійких позицій на міжнародному ринку. Необхідною умовою для цього $\epsilon$ формування в країні потужного конкурентоспроможного середовища, яке базується на інноваційних чинниках i забезпечує прорив на міжнародні ринки високотехнологічної продукції.

Висновки даного дослідження i перспективи подальших робіт у цьому напрямку. Процес глобалізації який охопив світову економіку вимагає від підприємств орієнтації на інноваційну спрямованість стратегії розвитку і $\epsilon$ невід'ємною умовою забезпечення його високої конкурентної позиції на зовнішніх ринках збуту, що, у свою чергу, $\epsilon$ запорукою прибутковості та фінансової стійкості підприємства. Разом 3 тим придбання підприємствами нових технологій, замовлення їх розробки науково-дослідним установам або розробка таких технологій власними дослідними лабораторіями підприємств на даний час мають вкрай обмежений характер в силу як суб'єктивних, так i об'єктивних причин. До об'єктивних причин слід віднести дію зовнішніх для підприємства чинників, таких як: низький стартовий рівень технологій вітчизняних підприємств у порівнянні зі світовими лідерами виробництва аналогічної за призначенням продукції; недостатній рівень фінансового забезпечення інноваційного розвитку підприємств у зв'язку 3 низькою їх конкурентоспроможністю як за якістю продукції, так i за іiї ціною, що обумовлюється високим рівнем матеріалоємності, енергоємності продукції та високим рівнем фізичного та морального зносу основних засобів виробництва; відсутність орієнтації власників капіталу на фінансування розвитку підприємства, спрямоване на отримання доходів через певний час, їх бажання отримати прибуток негайно за рахунок зниження витрат на робочу силу; вкладання власниками підприємств інвестицій у більш інвестиційнопривабливі підприємства за кордоном; недостатня розвиненість фінансового ринку України та порівняно високий рівень інфляції, що призводить до високої ціни та обмеженості середньо та довгострокових кредитних ресурсів, тощо. Новий підхід щодо розуміння ролі інновацій та інноваційного розвитку у забезпеченні глобальної конкурентоспроможності українських підприємств вимагає нової економічної стратегії, яка має враховувати такі завдання, як розвиток національної інноваційної системи та державна підтримка іiі основних інституцій; поглиблення інтернаціоналізації національної інноваційної системи на основі впровадження міжнародних стандартів забезпечення; збільшення частки наукоємної продукції в структурі експорту; збільшення обсягів фінансування фундаментальних i прикладних досліджень, в тому числі використання міжнародних механізмів проведення та фінансування НДДКР; впровадження прогресивних форм навчання i підготовки фахівців 3 об'єднанням зусиль держави і приватного сектору; активізація комерціалізації інновацій, створення каналів їх дифузії для забезпечення більш широкого освоєння нововведень.

Вісник економіки транспорту і промисловості № 61, 2018 
ПЕРЕЛІК ВИКОРИСТАНИХ ДЖЕРЕЛ

1 Говоруха Ж.А. Питання розвитку інноваційної діяльності підприємств України - Ж.А. Говоруха // Актуальні проблеми економіки. - 2017. - №8(74). C. $107-115$.

2 Гриньова В.М. Соціальноекономічні проблеми інноваційного розвитку підприємств: монографія / В.М. Гриньова, О.В. Козирєва. - Х.: ВД «ІНЖЕК», 2016. - 192 c.

3 Дикань В.Л. Інноваційний вектор забезпечення сталого розвитку економіки України / В.Л. Дикань, Б.Я. Остапюк // Вісник економіки транспорту i промисловості: збірник науковопрактичних статей. - 2012. - №39. - С. 1520.

4 Дикань В.Л. Концепція інноваційного розвитку економіки / В.Л. Дикань // Вісник економіки транспорту i промисловості: збірник науково-практичних статей. - 2015. №51. - C. 9-20.
5 Дикань В.Л. Стратегічні пріоритети розвитку економіки України в умовах зміни центрів економічної та політичної влади / В.Л. Дикань // Вісник економіки транспорту i промисловості: збірник науково-практичних статей. 2013. - №41. - C. 11-16.

6 Зубенко В.О. Зміна парадигми забезпечення конкурентоспроможності промислових підприємств України / В.О. Зубенко // Вісник економіки транспорту і промисловості: збірник науковопрактичних статей. - 2012. - №40. - С. 160-162.

7 Ілляшенко С.M. Управління інноваційним розвитком: навч. посіб. / С.М. Ілляшенко. - 2-ге вид., перероб. і доп. - Суми: ВТД «Університетська книга»; К.: Видавничий дім «Княгиня Ольга», 2015. - 324 с.

8 Федулова Л.І. Інноваційний розвиток промисловості України / Л.І. Федулова // Актуальні проблеми економіки. - 2017. - №3(69). - С. 83-97. 